\title{
Inhibitory Effects of Hypermagnesemia on the Renal Action of Parathyroid Hormone
}

\author{
E. Slatopolsky, A. Mercado, A. Morrison, J. Yates, and S. KLahr \\ From the Renal Division, Department of Medicine, Washington University \\ School of Medicine, St. Louis, Missouri 63110
}

A B S TRACT Available evidence indicates that serum magnesium $\left(\mathrm{Mg}^{++}\right)$levels influence the secretion rate of parathyroid hormone (PTH). Whether serum $\mathrm{Mg}^{++}$concentrations also modify the action of PTH on its target organs has not been definitively established. The present experiments were designed to study this possibility. The effect of infusing PTH on the urinary excretion of cyclic AMP (cAMP) and $\mathrm{PO}_{4}=$ was examined in five normal dogs at two different levels of serum $\mathrm{Mg}^{++}$. At normal serum $\mathrm{Mg}^{++}$concentrations $(1.89 \pm 0.14 \mathrm{mg} / 100 \mathrm{ml})$, PTH infusion increased cAMP excretion from $1.76 \pm 0.27$ to $4.87 \pm 1.00 \mathrm{nmol} / \mathrm{min}$ and fractional $\mathrm{PO}_{4}=$ excretion $\left(\mathrm{FE}_{\mathrm{PO}_{4}}\right)$ from $1.58 \pm 0.36 \%$ to $23.1 \pm 2.17 \%$. When an identical amount of PTH was given to the same dogs at a serum $\mathrm{Mg}^{++}$of $4.36 \pm 0.20 \mathrm{mg} / 100 \mathrm{ml}, \mathrm{FE}_{\mathrm{PO}_{4}}$ increased to only $6.02 \pm 1.89 \%$ and cAMP from $1.31 \pm 0.23$ to $1.89 \pm 0.39 \mathrm{nmol} / \mathrm{min}$. Identical results were obtained in thyroparathyroidectomized hypermagnesemic dogs. Increased serum $\mathrm{Mg}^{++}$levels had no effect on the phosphaturia produced by the infusion of dibutyryl cAMP to thyroparathyroidectomized dogs. In vitro studies using rat renal cortical slices revealed a progressive decrease in cAMP production in response to PTH as the $\mathrm{Mg}^{++}$concentrations were increased in the incubation medium. The overall results indicate that hypermagnesemia inhibits the phosphaturic response to PTH by decreasing the renal production of cAMP. Plasma magnesium, therefore, may participate in a double feedback mechanism, not only controlling the release of PTH, but also altering the biological activity of the hormone at the level of the target organ.

This work was presented in part at the National Meeting of the American Federation for Clinical Research, May 1975, and reported in abstract form in Clin. Res. 23: 374A.

During this study, Dr. Mercado was supported by a Research Fellowship from the International Center for Medical Research and Training.

Received for publication 30 April 1976 and in revised form 2 August 1976.

\section{INTRODUCTION}

Serum calcium and magnesium concentrations play an important role in the regulation of parathyroid hormone $(\mathrm{PTH})^{1}$ secretion. Both hypercalcemia and hypermagnesemia are known to suppress the release of PTH (1-6). It is possible that the relative serum concentrations of these ions may modify not only the release of parathyroid hormone but also the biological activity of PTH at the level of the target organs.

Recently, Beck and collaborators (7) have demonstrated that hypercalcemia modifies the renal response to PTH. Rats rendered hypercalcemic had a lesser increment in urinary phosphate and cyclic AMP (cAMP) excretion in response to PTH administration than hypo- or normocalcemic animals. Serum magnesium levels may also play an important role in regulating the biological activity of PTH. Hypomagnesemia is frequently accompanied by hypocalcemia (8-15), which apparently results from resistance of the skeleton to the action of PTH. However, controversial results have been obtained regarding the influence of hypomagnesemia on the release of PTH from the parathyroid glands $(8-15)$. The present studies were performed to determine the role of hypermagnesemia in the renal response to PTH administration. Urinary phosphate and cAMP excretion were determined in normo- and hypermagnesemic dogs before and after the administration of PTH. The effect of magnesium on the production of cAMP also was studied in vitro with rat renal cortical slices.

\section{METHODS}

21 experiments were performed on 16 female adult mongrel dogs weighing $12-20 \mathrm{~kg}$. All experiments were performed on unanesthetized, trained dogs. The animals were fed a standard dog chow, and they were in the Animal Care Facilities for at least 2 wk before any experiments were

${ }^{1}$ Abbreviations used in this paper: PTH, parathyroid hormone. 
TABLE I

Effect of PTH Administration on Urinary Phosphate and Cyclic AMP

Excretion in Five Normomagnesemic Dogs

\begin{tabular}{|c|c|c|c|c|c|c|c|c|c|}
\hline Dog & GFR & $\mathrm{S}_{\mathrm{Mg}}$ & $\mathrm{S}_{\mathrm{PO},}$ & $\mathrm{s}_{\mathrm{Ca}}$ & $\mathrm{S}_{\mathrm{ICa}}$ & $\mathrm{U}_{\mathrm{PO},} \mathrm{V}$ & $\mathrm{FE}_{\mathrm{PO} 4}$ & cAMP & $\mathrm{FE}_{\mathrm{Na}}$ \\
\hline & $\mathrm{ml} / \mathrm{min}$ & & & $\mathrm{mg} / 100 \mathrm{ml}$ & & $\mu g / \min$ & $\%$ & nmol/min & $\%$ \\
\hline \multirow[t]{2}{*}{1} & C 39.3 & 1.49 & 4.4 & 8.85 & 4.80 & 43.0 & 2.6 & 1.88 & 0.1 \\
\hline & E 50.8 & 1.49 & 4.0 & 9.29 & 5.09 & 620.0 & 30.3 & 4.38 & 0.1 \\
\hline \multirow[t]{2}{*}{2} & C 41.7 & 1.82 & 3.7 & 9.23 & 4.76 & 6.0 & 0.4 & 1.78 & 0.1 \\
\hline & E 60.4 & 1.27 & 3.5 & 8.81 & 4.76 & 532.0 & 24.8 & 3.33 & 0.4 \\
\hline \multirow[t]{2}{*}{3} & C 46.4 & 1.76 & 4.6 & 8.78 & 4.48 & 31.0 & 1.4 & 2.15 & 0.1 \\
\hline & E 61.7 & 1.58 & 3.8 & 9.14 & 4.84 & 542.0 & 22.8 & 6.06 & 0.3 \\
\hline \multirow[t]{2}{*}{4} & C 47.3 & 2.30 & 4.8 & 10.0 & 5.84 & 33.0 & 1.5 & 2.24 & 0.1 \\
\hline & E 80.0 & 2.18 & 4.7 & 10.3 & 5.95 & 667.0 & 17.8 & 8.14 & 0.3 \\
\hline \multirow[t]{2}{*}{5} & C 47.5 & 2.09 & 5.6 & 8.47 & 4.34 & 61.0 & 2.0 & 0.75 & 0.1 \\
\hline & E 57.2 & 1.90 & 5.6 & 8.06 & 4.22 & 631.0 & 19.7 & 2.46 & 0.5 \\
\hline Mean & C 44.4 & 1.89 & 4.6 & 9.07 & 4.84 & 34.8 & 1.58 & 1.76 & 0.10 \\
\hline SE & \pm 1.66 & \pm 0.14 & \pm 0.4 & \pm 0.26 & \pm 0.26 & \pm 8.9 & \pm 0.36 & \pm 0.27 & \pm 0.01 \\
\hline Mean & E 62.0 & 1.69 & 4.3 & 9.12 & 4.97 & 598.4 & 23.1 & 4.87 & 0.32 \\
\hline SE & \pm 4.9 & \pm 0.16 & \pm 0.38 & \pm 0.36 & \pm 0.28 & \pm 26.3 & \pm 2.17 & \pm 1.0 & \pm 0.07 \\
\hline
\end{tabular}

Abbreviations: GFR, glomerular filtration rate; $\mathrm{S}_{\mathrm{Mg}}$, serum magnesium; $\mathrm{S}_{\mathrm{PO}_{4}}$, serum phosphate; $\mathrm{S}_{\mathrm{Ca}}$, serum total calcium; $\mathrm{SI}_{\mathrm{Ca}}$, serum ionized calcium; $\mathrm{U}_{\mathrm{PO}_{4}} \mathrm{~V}$, urinary phosphate excretion; $\mathrm{FE}_{\mathrm{PO}_{4}}$, fractional excretion of phosphate; cAMP, urinary excretion of cyclic AMP; $\mathrm{FE}_{\mathrm{Na}}$, fractional excretion of sodium; $\mathrm{C}$, mean values of three control clearance periods; $\mathrm{E}$, mean values of five to six 20 to 30 -min experimental periods obtained after the administration of a prime dose of $100 \mathrm{U}$ of PTH followed by a sustaining infusion delivering $1 \mathrm{U}$ of $\mathrm{PTH} / \mathrm{min}$.

performed. The dogs were fasted for $16 \mathrm{~h}$ before the clearance studies, but they were allowed free access to water. On the morning of the experiments catheters were inserted in a hind limb vein for the infusion of solutions, in the jugular vein for the collection of blood samples, and in the bladder for urine collections. The dog received initially $300-500 \mathrm{ml}$ of tap water via gastric tube and intravenously a solution containing $5 \%$ creatinine in $2.5 \%$ dextrose in water as a prime. Thereafter, a sustaining solution containing creatinine in $2.5 \%$ dextrose in water was given at the rate of $2.5 \mathrm{ml} / \mathrm{min}$. The experimental protocols included:

Administration of PTH to normal dogs. (group 1). In a group of five normal dogs, after two to three baseline clearance periods were obtained, PTH (Parathyroid, Eli Lilly and Company, Indianapolis, Ind.), $100 \mathrm{U}$, was given as a prime, followed by the administration of $1 \mathrm{U} / \mathrm{min}$. Five to six additional clearance periods, of 20-30 min each, were collected during the administration of PTH.

Administration of PTH to hypermagnesemic dogs (group 2). These studies were performed in the same group of dogs 3-4 wk later. At the beginning of the experiments, 8.12 meq of magnesium sulfate were given i.v. as a prime dose, followed by the administration of $100 \mu \mathrm{eq} / \mathrm{min}$. The sustaining solution containing magnesium was $2.5 \%$ dextrose in water delivered at the rate of $2.5 \mathrm{ml} / \mathrm{min}$. After 90 min of equilibration, initial clearance periods were collected. Thereafter, PTH was given as described above and the same protocol was followed as above.

Administration of PTH to hypermagnesemic thyroparathyroidectomized dogs. Thyroparathyroidectomy was per- formed in four dogs. 1-2 $\mathrm{g}$ of calcium (as calcium lactate) were added to the diet to keep the dogs alive. Eventually all of the dogs expired with serum calcium values as low as $3.5 \mathrm{mg} / 100 \mathrm{ml}$. 2-3 days after parathyroidectomy, experiments were performed as in group 2.

Administration of sodium sulfate to normal dogs. In a group of four dogs, sodium sulfate was given intravenously, $8.12 \mathrm{meq}$ as a prime, followed by the administration of 100 $\mu \mathrm{eq} / \mathrm{min}$ in a $2.5 \%$ solution of dextrose in water delivered at $2.5 \mathrm{ml} / \mathrm{min}$. After $90 \mathrm{~min}$ of equilibration, base-line clearance periods were obtained. Thereafter, PTH was administered as in group 1 , while the dogs continued to receive $\mathrm{Na}_{2} \mathrm{SO}_{4}$. Five $20-30$-min periods were then collected.

Administration of dibutyryl cAMP to hypermagnesemic thyroparathyroidectomized dogs. In a group of four thyroparathyroidectomized dogs, magnesium was given as in group 2. After base-line collections were obtained, dibutyryl cAMP (Sigma Chemical Co., St. Louis, Mo.) was given i.v. at the rate of $1.5 \mathrm{mg} / \mathrm{min}$. Thereafter, four to five additional clearance periods were collected.

Effects of magnesium concentrations on cAMP production in response to PTH by rat renal cortical slices. Rat renal cortical slices, prepared as described previously (16), were incubated in Krebs-Ringer solution containing $10 \mathrm{mM}$ theophylline at $\mathrm{Mg}^{++}$concentrations of $1,2.5,5$, and $10 \mathrm{mM}$. At each level of magnesium concentration, cAMP production was measured in the absence (control) and presence (experimental) of $1 \mathrm{U}$ of synthetic bovine PTH 1-34 (Beckman Instruments, Inc., Palo Alto, Calif.). The flasks were incubated in a Dubnoff metabolic shaker for $20 \mathrm{~min}$ at $37^{\circ} \mathrm{C}$, and gassed with a $95 \% \mathrm{O}_{2}, 5 \% \mathrm{CO}_{2}$ mixture. The reaction 
TABLE II

Effect of PTH Administration on Urinary Phosphate and Cyclic AMP Excretion in Five Hypermagnesemic Dogs

\begin{tabular}{|c|c|c|c|c|c|c|c|c|c|}
\hline Dog & GFR & $S_{M B}$ & $\mathrm{~S}_{\mathrm{PO}, 4}$ & $\mathrm{~S}_{\mathrm{Ca}}$ & $\mathrm{SI}_{\mathrm{Ca}}$ & $\mathrm{U}_{\mathrm{PO}, \mathrm{V}} \mathrm{V}$ & $\mathrm{FE}_{\mathrm{PO}}$ & cAMP & $\mathrm{FE}_{\mathrm{Na}}$ \\
\hline \multicolumn{3}{|c|}{$\mathrm{ml} / \mathrm{min}$} & \multicolumn{3}{|c|}{$\mathrm{mg} / 100 \mathrm{ml}$} & $\mu g / \min$ & $\%$ & nmol/min & $\%$ \\
\hline 1 & $\begin{array}{ll}\text { C } 39.0 \\
\text { E } 51.3\end{array}$ & $\begin{array}{l}5.08 \\
5.06\end{array}$ & $\begin{array}{l}4.5 \\
3.8\end{array}$ & $\begin{array}{l}8.35 \\
7.86\end{array}$ & $\begin{array}{l}4.72 \\
4.45\end{array}$ & $\begin{array}{r}6.4 \\
263.0\end{array}$ & $\begin{array}{r}0.3 \\
13.2\end{array}$ & $\begin{array}{l}1.38 \\
1.54\end{array}$ & $\begin{array}{l}0.1 \\
1.3\end{array}$ \\
\hline 2 & $\begin{array}{l}\text { C } 49.5 \\
\text { E } 63.8\end{array}$ & $\begin{array}{l}4.17 \\
3.85\end{array}$ & $\begin{array}{l}2.8 \\
2.3\end{array}$ & $\begin{array}{l}8.00 \\
7.25\end{array}$ & $\begin{array}{l}4.70 \\
4.28\end{array}$ & $\begin{array}{r}6.6 \\
52.6\end{array}$ & $\begin{array}{l}0.5 \\
3.3\end{array}$ & $\begin{array}{l}1.41 \\
1.92\end{array}$ & $\begin{array}{l}0.4 \\
0.8\end{array}$ \\
\hline 3 & $\begin{array}{l}\text { C } 45.1 \\
\text { E } 68.4\end{array}$ & $\begin{array}{l}3.93 \\
4.13\end{array}$ & $\begin{array}{l}4.3 \\
4.3\end{array}$ & $\begin{array}{l}9.35 \\
9.39\end{array}$ & $\begin{array}{l}4.56 \\
4.85\end{array}$ & $\begin{array}{r}7.9 \\
174.4\end{array}$ & $\begin{array}{l}0.4 \\
5.2\end{array}$ & $\begin{array}{l}1.99 \\
3.25\end{array}$ & $\begin{array}{l}0.1 \\
0.9\end{array}$ \\
\hline 4 & $\begin{array}{ll}\text { C } & 43.3 \\
\text { E } & 99.9\end{array}$ & $\begin{array}{l}4.53 \\
4.18\end{array}$ & $\begin{array}{l}5.2 \\
4.5\end{array}$ & $\begin{array}{l}10.2 \\
10.2\end{array}$ & $\begin{array}{l}5.48 \\
5.26\end{array}$ & $\begin{array}{r}14.5 \\
195.8\end{array}$ & $\begin{array}{l}0.6 \\
5.8\end{array}$ & $\begin{array}{l}0.55 \\
0.85\end{array}$ & $\begin{array}{l}0.1 \\
0.4\end{array}$ \\
\hline 5 & $\begin{array}{l}\text { C } 52.0 \\
\text { E } 63.2\end{array}$ & $\begin{array}{l}4.12 \\
4.07\end{array}$ & $\begin{array}{l}3.8 \\
3.3\end{array}$ & $\begin{array}{l}8.84 \\
8.35\end{array}$ & $\begin{array}{l}4.68 \\
4.56\end{array}$ & $\begin{array}{l}20.6 \\
52.2\end{array}$ & $\begin{array}{l}1.0 \\
2.6\end{array}$ & $\begin{array}{l}1.21 \\
1.91\end{array}$ & $\begin{array}{l}0.1 \\
0.8\end{array}$ \\
\hline $\begin{array}{l}\text { Mean } \\
\text { SE }\end{array}$ & $\begin{array}{r}\mathrm{C} 45.8 \\
\pm 2.3\end{array}$ & $\begin{array}{r}4.37 \\
\pm 0.20\end{array}$ & $\begin{array}{r}4.1 \\
\pm 0.4\end{array}$ & $\begin{array}{r}8.95 \\
+0.39\end{array}$ & $\begin{array}{r}4.83 \\
\pm 0.17\end{array}$ & $\begin{array}{r}11.2 \\
\pm 2.8\end{array}$ & $\begin{array}{r}0.56 \\
\pm 0.12\end{array}$ & $\begin{array}{r}1.31 \\
\pm 0.23\end{array}$ & $\begin{array}{r}0.16 \\
\pm 0.06\end{array}$ \\
\hline $\begin{array}{l}\text { Mean } \\
\text { SE }\end{array}$ & $\begin{array}{r}\text { E } 63.3 \\
\pm 3.3\end{array}$ & $\begin{array}{r}4.26 \\
\pm 0.21\end{array}$ & $\begin{array}{r}3.6 \\
\pm 0.4\end{array}$ & $\begin{array}{r}8.61 \\
\pm 0.53\end{array}$ & $\begin{array}{r}4.68 \\
\pm 0.17\end{array}$ & $\begin{array}{r}147.6 \\
\pm 41.6\end{array}$ & $\begin{array}{r}6.02 \\
\pm 1.89\end{array}$ & $\begin{array}{r}1.89 \\
\pm 0.39\end{array}$ & $\begin{array}{r}0.84 \\
\pm 0.14\end{array}$ \\
\hline
\end{tabular}

For explanation of abbreviations see Table I. C, mean values of three control clearance periods after the dogs had received a prime dose of 8.12 meq of magnesium sulfate intravenously, followed by a sustaining infusion delivering $100 \mu \mathrm{eq} / \mathrm{min}$ of magnesium sulfate; $\mathrm{E}$, mean values of five to six experimental periods obtained after the administration of $100 \mathrm{U}$ of PTH, followed by a sustaining infusion delivering $1 \mathrm{U} / \mathrm{min}$.

was terminated by quickly removing the slices, freezing them in Freon (E. I. duPont de Nemours \& Co., Inc., Wilmington, Del.), and transferring them to $1 \mathrm{ml} 50 \mathrm{mM}$ $\mathrm{Na}$ acetate-acetic acid buffer, $\mathrm{pH} \mathrm{4}$, and boiling them for 3-5 min. They were then homogenized in a glass homogenizer, and an aliquot was removed for protein determination and the remainder spun at $6,000 \mathrm{~g}$ for $20 \mathrm{~min}$. The supernatant was assayed for cAMP by a modification of the protein binding assay of Gilman (17) as described previously (16). cAMP was also assayed in the incubation media and total cAMP produced was expressed as cAMP per milligram protein per 20 minutes. Protein was determined by the method of Lowry et al. (18).

Effects of magnesium concentrations on adenyl cyclase activity in response to $P$ TH by rat renal cortical slices. Membranes were prepared by the method of Marcus and Aurbach (19), using the cortical slices from adult Holtzman rats, and stored in small aliquots at $-70^{\circ} \mathrm{C}$. Enzyme activity was measured in the absence of PTH (syn 1-34) and at concentrations of PTH of 1 and $10 \mathrm{U} / \mathrm{ml}$. The activities were determined over the range of $\mathrm{Mg}^{++}$concentrations $0,1,5,10$, and $20 \mathrm{mM}$. Adenyl cyclase activity was measured by the method of Salomon et al. (20).

Analytical Procedures. Glomerular filtration rate (GFR) was measured by the exogenous creatinine clearance; phosphate clearance was measured concurrently. Creatinine concentrations in urine and plasma were determined by the Jaffe reaction, as dexcribed by Eolin (21) and adapted for the Technicon Autoanalyzer (Technicon Instruments Corp., Tarrytown, N. Y.). Phosphate was measured by the method of Kraml and Hurst $(22,23)$, as adapted for the Technicon Autoanalyzer. Calcium and magnesium were measured with an atomic absorption spectrophotometer (Perkin-Elmer Corp., Norwalk, Conn., model 503). Ionized calcium was measured anaerobically with a flow-through electrode (Orion Research Inc., Cambridge, Mass.). Urinary and plasma sodium was measured with an IL flame photometer (Instrumentation Laboratory, Inc., Lexington, Mass., model 143), and urinary cAMP was measured by a modification of the method of Gilman (17) previously reported (16). Standard formulas were used for the calculation of creatinine clearance and fractional excretion of sodium and phosphate. Statistics used Student's $t$ test for paired data.

\section{RESULTS}

Tables I and II summarize the effects of PTH administration on urinary phosphate and cAMP excretion during normomagnesemia and hypermagnesemia in five dogs. In normomagnesemia PTH administration increased phosphate excretion from $34.8 \pm 8.9$ to $598.4 \pm 26.3 \mu \mathrm{g} / \mathrm{min}$. cAMP increased from $1.76 \pm 0.27$ to a peak response of $4.87 \pm 1.0 \mathrm{nmol} / \mathrm{min}$. When the animals were rendered hypermagnesemic, mean serum magnesium was $4.37 \pm 0.2 \mathrm{mg} / 100 \mathrm{ml}$ before the infusion of PTH, and $4.26 \pm 0.21 \mathrm{mg} / 100 \mathrm{ml}$ after PTH administration. Phosphate excretion increased from $11.2 \pm 2.8$ to $147.6 \pm 41.6 \mu \mathrm{g} / \mathrm{min}$. Fractional phosphate excretion increased from $0.56 \pm 0.12 \%$ to only 6.02 $\pm 1.89 \%$ in comparison to $23.1 \pm 2.17$ in the normomagnesemic animals. Cyclic AMP increased from 1.31 
TABLE III

Effect of PTH administration on Urinary Phosphate Excretion in Four Thyroparathyroidectomized Hypermagnesemic Dogs

\begin{tabular}{|c|c|c|c|c|c|c|c|c|}
\hline & GRF & $\mathrm{S}_{\mathrm{MB}}$ & $\mathrm{S}_{\mathrm{PO}_{4},}$ & $\mathrm{~S}_{\mathrm{ca}}$ & $\mathrm{S}_{\mathrm{ICa}}$ & $\mathrm{U}_{\mathrm{PO}, 4} \mathrm{~V}$ & $\mathrm{FE}_{\mathrm{PO}}$ & $\mathrm{FE}_{\mathrm{Na}}$ \\
\hline & $\mathrm{ml} / \mathrm{min}$ & \multicolumn{4}{|c|}{$\mathrm{mg} / 100 \mathrm{ml}$} & $\mu \mathrm{g} / \mathrm{min}$ & $\%$ & $\%$ \\
\hline & C 46.7 & 5.34 & 5.0 & 7.0 & 3.40 & 49.5 & 2.1 & 0.1 \\
\hline & E 60.6 & 5.01 & 3.6 & 6.5 & 3.25 & 131.1 & 6.3 & 1.8 \\
\hline & C 57.4 & 4.88 & 3.3 & 8.41 & 4.44 & 25.5 & 0.1 & 0.1 \\
\hline & E 78.3 & 4.96 & 3.2 & 8.75 & 4.68 & 56.0 & 2.1 & 0.4 \\
\hline & C 52.5 & 4.59 & 4.8 & 7.74 & 3.60 & 3.5 & 0.1 & 0.1 \\
\hline & E 75.1 & 4.49 & 4.6 & 8.15 & 4.07 & 43.6 & 1.4 & 1.1 \\
\hline & C 31.4 & 4.99 & 3.3 & 8.26 & 4.32 & 7.7 & 0.7 & 0.1 \\
\hline & E 38.6 & 5.18 & 2.9 & 7.79 & 4.21 & 66.9 & 6.1 & 1.6 \\
\hline Mean & C 47.00 & 4.95 & 4.1 & 7.85 & 3.94 & 21.6 & 0.75 & 0.1 \\
\hline $\mathrm{SE}$ & \pm 5.50 & \pm 0.16 & \pm 0.93 & \pm 0.32 & \pm 0.26 & \pm 10.5 & \pm 0.47 & \pm 0.00 \\
\hline Mean & E 63.2 & 4.91 & 3.58 & 7.81 & 4.05 & 74.4 & 3.98 & 1.23 \\
\hline SE & \pm 9.0 & \pm 0.15 & \pm 0.37 & \pm 0.48 & \pm 0.30 & \pm 19.5 & \pm 1.30 & \pm 0.31 \\
\hline
\end{tabular}

For explanation of abbreviations see Table I. Dogs were thyroparathyroidectomized 2 or 3 days before these experiments.

$\pm 0.23 \mathrm{nmol} / \mathrm{min}$ to a peak response of $1.89 \pm 0.39$ $\mathrm{nmol} / \mathrm{min}$.

To rule out a possible contribution of endogenous PTH, similar experiments were performed in a group of thyroparathyroidectomized hypermagnesemic dogs. Identical results were obtained in these animals. Phosphate excretion increased from $21.6 \pm 10.5 \mu \mathrm{g} /$ min to only $74.4 \pm 19.5 \mu \mathrm{g} / \mathrm{min}$. Fractional phosphate excretion increased from $0.75 \pm 0.47 \%$ to only 3.98 $\pm 1.30 \%$ (Table III).

These observations suggest that magnesium may

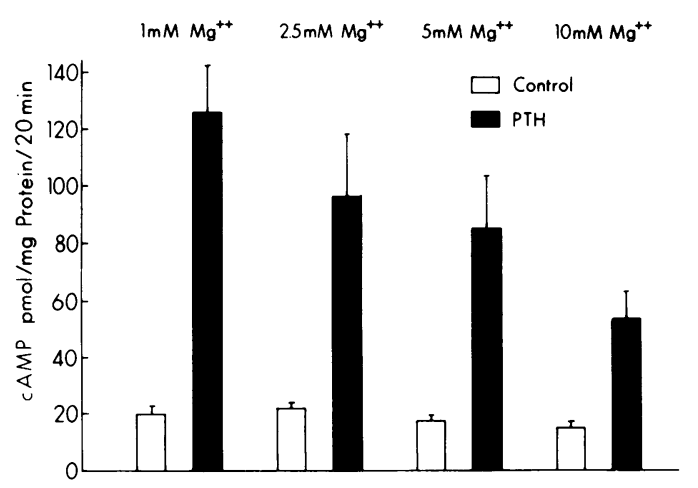

FIGURE 1 Effects of increasing magnesium concentrations on cAMP production by rat renal cortical slices in response to $\mathrm{PTH}$. The concentration of $\mathrm{Mg}$ in the medium ranged from 1 to $10 \mathrm{mM}$. cAMP was measured in the absence (control) and presence (experimental) of $1 \mathrm{U}$ of synthetic bovine PTH 1-34. Results are the mean and SE of the mean for eight experiments. interfere with the phosphaturic effect of PTH. Since magnesium was given as the sulfate salt, the results observed may be due to an increase in plasma sulfate. To determine if the "blunted" phosphaturic response to PTH was due to sulfate rather than magnesium, similar experiments were performed in a group of four dogs; however, in these animals sodium sulfate instead of magnesium sulfate was given i.v. at the rate of $100 \mu \mathrm{eq} / \mathrm{min}$. There were no changes in total or ionized serum calcium, phosphorus, or magnesium after the administration of PTH. Glomerular filtration rate increased from $64.6 \pm 3.1$ to $74.1 \pm 3.1$ $\mathrm{ml} / \mathrm{min}$. Fractional phosphate excretion increased from $6.16 \pm 3.0$ to $30.7 \pm 3.1$. Thus sulfate did not affect the phosphaturic effect of PTH.

Since the phosphaturic effect of PTH is mediated, at least in part, by CAMP, hypermagnesemia may interfere with the renal action of PTH by inhibiting the production of cAMP. To examine this possibility, studies were performed in vitro. The production of cAMP in response to PTH was studied in rat renal cortical slices incubated in varying concentrations of magnesium. Fig. 1 depicts the results of cAMP production obtained in a series of experiments in which the amount of magnesium in the Ringer's solution ranged from 1 to $10 \mathrm{mM}$. cAMP production is shown under control conditions and after the addition of $1 \mathrm{U}$ of synthetic PTH 1-34 to the medium. There was an inverse relationship between the concentration of magnesium in the medium and the amount of cAMP produced. At a concentration of $1 \mathrm{mM}$ magnesium in the medium, the addition of PTH increased cAMP 
TABLE IV

Effect of Dibutyryl Cyclic AMP Administration on Phosphate Excretion in Four Thyroparathyroidectomized Hypermagnesemic Dogs

\begin{tabular}{|c|c|c|c|c|c|c|c|c|}
\hline & GFR & $\mathrm{S}_{\mathrm{Mz}}$ & $\mathrm{S}_{\mathrm{PO} \text {. }}$ & $\mathbf{S}_{\mathrm{ca}}$ & $\mathbf{S}_{\mathrm{ICa}}$ & $\mathrm{U}_{\mathrm{PO}_{0} \mathrm{~V}}$ & $\mathrm{FE}_{\mathrm{PO} \text {, }}$ & $\mathrm{FE}_{\mathrm{Na}}$ \\
\hline & $\mathrm{ml} / \mathrm{min}$ & \multicolumn{4}{|c|}{$\mathrm{mg} / 100 \mathrm{ml}$} & $\mu \mathrm{g} / \mathrm{min}$ & $\%$ & $\%$ \\
\hline & C 45.7 & 6.76 & 4.28 & 6.76 & 3.02 & 7.3 & 0.3 & 0.63 \\
\hline & E 57.3 & 6.19 & 3.29 & 5.00 & 2.89 & 447.7 & 27.0 & 2.32 \\
\hline & C 41.8 & 5.15 & 3.74 & 8.60 & 4.56 & 30.1 & 1.9 & 0.04 \\
\hline & E 53.8 & 5.71 & 3.02 & 8.16 & 4.32 & 417.3 & 26.1 & 2.15 \\
\hline & C 25.3 & 5.17 & 3.60 & 8.79 & 4.48 & 2.4 & 0.2 & 0.10 \\
\hline & E 44.3 & 4.92 & 2.30 & 7.95 & 3.85 & 174.0 & 16.7 & 0.60 \\
\hline & C 42.5 & 5.30 & 4.9 & 7.70 & 3.7 & 8.4 & 0.3 & 0.10 \\
\hline & E 56.3 & 5.15 & 4.1 & 7.10 & 3.4 & 405.1 & 23.0 & 0.80 \\
\hline Mean & C 38.8 & 5.69 & 4.13 & 7.96 & 3.94 & 12.1 & 0.68 & 0.22 \\
\hline SE & \pm 4.6 & \pm 0.40 & \pm 0.30 & \pm 0.47 & \pm 0.36 & \pm 6.2 & \pm 0.41 & \pm 0.14 \\
\hline Mean & E 52.9 & 5.49 & 3.18 & 7.05 & 3.67 & 361.1 & 23.2 & 1.47 \\
\hline SE & \pm 2.97 & \pm 0.29 & \pm 0.37 & \pm 0.72 & \pm 0.42 & \pm 62.9 & \pm 2.33 & \pm 0.45 \\
\hline
\end{tabular}

For explanation of abbreviations, see Table I.

production from $20.5 \pm 1.6$ to $125 \pm 18.2 \mathrm{pmol} / \mathrm{mg}$ protein per $20 \mathrm{~min}$. At a concentration of $10 \mathrm{mM}$ magnesium, the addition of PTH increased cAMP production from $14.8 \pm 2.0$ to only $54.7 \pm 11.0 \mathrm{pmol} / \mathrm{mg}$ protein per $20 \mathrm{~min}$.

The activity of the adenyl cyclase system was also evaluated at varying concentrations of magnesium in the medium before and after the addition of PTH. When magnesium was omitted from the medium, the activity of the enzyme was low, $12 \pm 7.8 \mathrm{pmol} / \mathrm{mg}$ protein per $10 \mathrm{~min}$ of incubation, and there was no stimulation by the addition of 1 or $10 \mathrm{U}$ of PTH. The activity of the adenyl cyclase was greatly enhanced by addition of magnesium, and at $5 \mathrm{mM}$ the production of cAMP was $398 \pm 35.9 \mathrm{pmol} / \mathrm{mg}$ protein per 10-min incubation. A twofold increase in adenyl cyclase activity was seen when PTH was added to the medium. Similar results were observed at a magnesium concentration of $20 \mathrm{mM}$.

To further delineate the role of magnesium in the cAMP-mediated phosphaturic effect of PTH, additional studies were performed in vivo. Table IV illustrates the results obtained in four thyroparathyroidectomized hypermagnesemic dogs before and after administration of dibutyryl cAMP. As seen with PTH, GFR also increased from a mean value of 38.8 to $52.9 \mathrm{ml} / \mathrm{min}$. Serum magnesium did not change appreciably, $5.69 \pm 0.40 \mathrm{mg} / 100 \mathrm{ml}$ before and $5.49 \pm 0.29 \mathrm{mg} / 100$ $\mathrm{ml}$ after cAMP infusion. The hypermagnesemia did not block the phosphaturic effect of dibutyryl cAMP and fractional phosphate excretion rose from 0.68 $\pm 0.41 \%$ to $23.2 \pm 2.33 \%$ after cAMP administration.

\section{DISCUSSION}

The levels of serum calcium and magnesium play an important role in the regulation of PTH secretion. Increased levels of serum calcium or magnesium inhibit the release of PTH (1-6). Beck et al. (7) have demonstrated recently that hypercalcemia modifies the phosphaturic response to $\mathrm{PTH}$ administration, raising the possibility of a role for calcium not only in the secretion of the hormone but also as a regulator of the peripheral actions of the hormone. The present studies strongly suggest that magnesium may play a similar role. Hypermagnesemia may not only affect PTH secretion but also alter the phosphaturic response observed after PTH administration in the dog. In our studies, the phosphaturic response secondary to the administration of PTH was greatly diminished when the concentration of magnesium in serum was increased from 1.9 to $4.3 \mathrm{mg} / 100 \mathrm{ml}$. This effect was seen both in normal and thyroparathyroidectomized animals, suggesting that hypermagnesemia affected renal phosphate excretion in the absence of endogenous PTH secretion. Concomitantly, with the decreased phosphaturia produced by hypermagnesemia, there was a remarkable decrease in the urinary excretion of cAMP in response to PTH administration. It should be remembered, however, that urinary cAMP represents not only the cAMP produced by the kidney itself but also circulating cAMP filtered and excreted by the kidney. Hence, a decrease in the urinary excretion of cAMP may result not only from decreased renal production per se but from decreased plasma 
levels with a fall in filtered cAMP. Since PTH administration increases the release of cAMP from bone (24-26), it is possible that some of the fall in the urinary excretion of cAMP may have been related to decreases in plasma cAMP secondary to decreased release of the nucleotide from bone in response to PTH administration during hypermagnesemia. However, the in vitro experiments with rat cortical renal slices clearly indicate that changes in the concentration of magnesium in the incubating medium result in progressive decreases in cAMP generation by rat renal cortex. The i.v. administration of dibutyryl cAMP to hypermagnesemic dogs clearly resulted in a phosphaturic response similar to that observed in normal magnesemic dogs (Table I). These data suggest that the effects of hypermagnesemia in blunting the phosphaturic response to PTH occur before the generation of cAMP. Decreased cAMP production by the kidney could result from either decreased activation of adenyl cyclase activity in response to PTH when magnesium is elevated or increased degradation of cAMP formed by phosphodiesterase. Studies by others have suggested that phosphodiesterase activity is maximal at $2 \mathrm{mM}$ magnesium and that increases in magnesium up to $10 \mathrm{mM}$ do not affect the activity of phosphodiesterase (27). Observations by Drummond and Perrott-Yee (28) have shown that rabbit brain phosphodiesterase is inhibited by magnesium at concentrations of about $0.8 \mathrm{mM}$. These data would tend to suggest that phosphodiesterase activation by hypermagnesemia is an unlikely explanation for the results obtained in the present studies. Moreover, in the in vitro studies $10 \mathrm{mM}$ theophylline was added to the medium so that the possibility that high concentrations of magnesium enhanced phosphodiesterase activity is somewhat remote. The second explanation for the decreased urinary cAMP excretion and the decreased production of cAMP by rat renal cortical slices at high levels of magnesium relates to an inhibitory effect of magnesium on the renal adenyl cyclase system in response to PTH. The results that we obtained, however, argue against this possibility. In broken renal cell membranes, hypermagnesemia did not inhibit the activation of adenyl cyclase produced by two different concentrations of PTH. While these results argue against invoking inhibition of adenyl cyclase as the mechanism responsible for the decreased excretion of cAMP observed during hypermagnesemic states and the decreased production observed in rat renal cortical slices, it is possible that the events in vivo and in vitro differ somewhat and the lack of inhibition with broken membranes may not completely exclude the possibility of inhibition of adenyl cyclase by increasing concentrations of magnesium in vivo. Moreover, the activity in vitro of adenylate cyclase is affected not only by changes in magnesium concentration but also in response to changes in magnesium to ATP ratios (19).

Additional experiments with rat cortical slices in vitro (results not reported) were designed to exclude a role of $\mathrm{Ca}^{++}$in the inhibition of cAMP production observed with increasing magnesium concentrations. Magnesium levels could affect $\mathrm{Ca}^{++}$entry into cells and influence cAMP generation in response to PTH. However, preincubation of renal cortical slices in $\mathrm{Ca}^{++}$-free medium containing $0.5 \mathrm{mM}$ EGTA for $30 \mathrm{~min}$, followed by reincubation of the slices in $\mathrm{Ca}^{++}$ free medium and varying concentrations of magnesium, resulted in decreased response to PTH as magnesium was raised, and the results were identical to those reported in Fig. 1. These results suggest that magnesium levels do not affect cAMP production by slices through a mechanism dependent on external calcium.

An alternative explanation may be related to an effect of magnesium on the binding of PTH to receptor sites. It is possible that hypermagnesemia decreases the binding and/or degradationof PTH. Massry and collaborators (5) demonstrated that when high doses of PTH are administered to hypermagnesemic dogs, a normal phosphaturic response is observed. We have obtained similar results during hypermagnesemia when the doses of PTH used were markedly increased. Under these conditions urine cAMP also increased. Thus, it is possible that magnesium may affect the biological activity of PTH by decreasing its binding to receptor sites or by accelerating its degradation. No experimental data in support or against this hypothesis are presently available.

The present studies suggest that the divalent cations, calcium and magnesium, may participate in a double feedback mechanism, not only controlling the release of PTH but also altering the biological activity of the hormone at the target organs. Thus, both hypermagnesemia and hypercalcemia would inhibit PTH release and would affect, at least at the level of the kidney, the phosphaturic response produced by the hormone. The present studies suggest that hypermagnesemia partially inhibits the phosphaturic response to PTH and the results are more consistent with the fact that this inhibition is primarily due to an impairment of PTH stimulation of cAMP production by the renal cortex. Hypermagnesemia was shown to be without effect on the phosphaturic effect of cAMP.

The effects of hypermagnesemia on the response of other target organs to PTH has not been explored. Hahn and collaborators (29) have studied the renal and skeletal responses to PTH in hypomagnesemic rats. They have demonstrated that hypomagnesemia does not alter the functional activity of PTH at the levels of kidney or bone. However, other investigators have suggested that the biological action of PTH at the level of the skeleton was impaired 
in the presence of hypomagnesemia (10-15). These latter studies suggest, therefore, that magnesium concentrations may not only affect the renal response to PTH hormone but also affect the action of the hormone at the level of another target organ, bone.

\section{ACKNOWLEDGMENTS}

We would like to express our appreciation to Dr. Howard Rasmussen for his advice, to Ms. Jane Lewis, Mrs. Claire Pedersen, Mrs. Sue King, and Ms. Margaret Reich for their technical assistance, and to Mrs. Patricia Verplancke for her secretarial assistance.

This work was supported by U. S. Public Health Service National Institute of Arthritis and Metabolic Disease grants AM-05248, AM-09976, and AM-07126.

\section{REFERENCES}

1. Sherwood, L. M., J. T. Potts, Jr., A. D. Care, G. P. Mayer, and G. D. Aurbach. 1966. Evaluation by radioimmunoassay of factors controlling the secretion of parathyroid hormone. Nature (Lond.) 209: 52-55.

2. Care, A. D., L. M. Sherwood, J. T. Potts, Jr., and G. D. Aurbach. 1966. Perfusion of the isolated parathyroid gland of the goat and sheep. Nature (Lond.). 209: 55-57.

3. Arnaud, C. D., Jr., A. M. Tenehouse, and H. Rasmussen. 1967. Parathyroid hormone. Annu. Rev. Physiol. 29: 349372.

4. Buckle, R. M., A. D. Care, C. W. Cooper, and H. J. Gitelman. 1968. The influence of plasma magnesium concentration of parathyroid hormone secretion. J. Endocrinol. 42: $529-534$

5. Massry, S., J. W. Coburn, and C. R. Kleeman. 1970. Evidence for suppression of parathyroid gland activity by hypermagnesemia. J. Clin. Invest. 49: 16191629.

6. Habener, J. F., and J. T. Potts, Jr. 1976. Relative effectiveness of magnesium and calcium on the secretion of biosynthesis of parathyroid hormone in vitro. Endocrinology. 98: 197-202.

7. Beck, N., H. Singh, S. W. Reed, and B. B. Davis. 1974. Direct inhibitory effect of hypercalcemia on renal actions of parathyroid hormone. J. Clin. Invest. 53: 717725.

8. Anast, C. S., J. M. Mohs, S. L. Kaplan, and T. W. Burns. 1972. Evidence for parathyroid failure in magnesium deficiency. Science (Wash. D. C.). 177: 606-608.

9. Suh, S. M. A. H. Tashjian, Jr., N. Matsuo, D. K. Parkinson, and D. Fraser. 1973. Pathogenesis of hypocalcemia in primary hypomagnesemia: Normal end-organ responsiveness to parathyroid hormone, impaired parathyroid gland function. J. Clin. Invest. 52: 153-160.

10. Estep, H., W. A. Shaw, C. Watlington, R. Hobe, W. Holland, and St. G. Tucker. 1969. Hypocalcemia due to hypomagnesemia and reversible parathyroid hormone unresponsiveness. J. Clin. Endocrinol. Metab. 29: 842848.

11. Muldowney, F. P., T. J. McKenna, L. H. Kyle, R. Freaney, and M. Swan. 1970. Parathormone-like effect of magnesium replenishment in steatorrhea. N. Engl. J. Med. 282: 61-68.
12. Woodward, J. C., P. D. Webster, and A. A. Carr. 1972. Primary hypomagnesemia with secondary hypocalcemia, diarrhea and insensitivity to parathyroid hormone. Am. J. Dig. Dis. 17: 612-618.

13. Paunier, L., I. C. Radde, S. W. Kooh, P. E. (Conen, and D. Fraser. 1968. Primary hypomagnesemia with secondary hypocaclemia in an infant. Pediatrics. 41: 385-402.

14. Conner, T. B., P. Toskes, J. Mahaffey, L. G. Martin, J. B. Williams, and M. Walser. 1972. Parathyroid function during chronic magnesium deficiency.Johns Hopkins Med.J. 131: 100-117.

15. Chase, L. R., and E. Slatopolsky. 1974. Secretion and metabolic efficacy of parathyroid hormone in patients with severe hypomagnesemia.J. Clin. Endocrinol. Metab. 38: $363-371$.

16. Rodriguez, H. J., J. Walls, J. Yates, and S. Klahr. 1974. Effects of acetazolamide on the urinary excretion of cyclic AMP and on the activity of renal adenyl cyclase. J. Clin. Invest. 53: 122-130.

17. Gilman, A. G. 1970. A proteın bindıng assay for adenosine 3':5'-cyclic monophosphate. Proc. Natl. Acad. Sci. U.S.A. 67: 305-312.

18. Lowry, O. H., N. J. Rosebrough, A. L. Farr, and R. J. Randall. 1951. Protein measurement by the Folin phenol reagent. J. Biol. Chem. 193: 265-275.

19. Marcus, R., and G. D. Aurbach. 1969. Bioassay of parathyroid hormone in vitro with a stable preparation of adenyl cyclase from rat kidney. Endocrinology. 85: 801810.

20. Salomon, Y., C. Londos, and M. Rodbell. 1974. A highly sensitive adenylate cyclase assay. Anal. Biochem. 58: $541-548$.

21. Hawk, P. B., B. L. Oser, and W. H. Summerson. 1947. Practical Physiological Chemistry. Blakiston Div. McGraw-Hill Book Comparny, New York. 12th edition, 506.

22. Kraml, M. 1966. A semi-automated determination of phospholipids. Clin. Chim. Acta. 13: 442-448.

23. Hurst, R. O. 1967. A simplified approach to the use of determinants in the calculation of the rate equation for a complex enzyme system. Can. J. Biochem. 45: 2015-2039.

24. Aurbach, G. D., and L. R. Chase. 1970. Cyclic 3', 5 -adenylic acid in bone and the mechanism of action of parathyroid hormone. Fed. Proc. 29: 1179-1182.

25. Peck, W. A., J. Carpenter, K. Messinger, and D. De Bra, 1973. Cyclic $3^{\prime}, 5^{\prime}$ adenosine monophosphate in isolated bone cells: Response to low concentrations of parathyroid hormone. Endocrinology. 92: 692-697.

26. Smith, D. M., and C. Johnston, Jr. 1974. Hormonal responsiveness of adenylate cyclase activity from separated bone cells. Endocrinology 95: 130-139.

27. Cheung, W. Y. 1967. Properties of cyclic $3^{\prime}, 5^{\prime}$-nucleotide phosphodiesterase from rat brain. Biochemistry. 6: 1079-1087.

28. Drummond, G. I., and S. Perrott-Yee. 1961. Enzymatic hydrolysis of adenosine 3 ',5'-phosphoric acid. J. Biol. Chem. 236: 1126-1129.

29. Hahn, T. J., L. R. Chase, and L. V. Avioli, 1972. Effect of magnesium depletion on responsiveness to parathyroid hormone in parathyroidectomized rats. J. Clin. Invest. 51: 886-891. 